\title{
ANALISIS PENGARUH KEMIRINGAN PIPA OUTLET TERHADAP EFISIENSI POMPA HIDRAM
}

\author{
Agus Putrawan', Sirajuddin haji Abdullah ${ }^{*}$, Asih Priyati $^{1}$ \\ ${ }^{1}$ Teknik Pertanian, Universitas Mataram, Indonesia \\ *Co-author: sirajuddinhajiabdullah@gmail.com
}

Article Information
History:
Received: $30-07-20$
Accepted: $30-10-20$

Keywords:

Hydram pump efficiency Outlet pipe slope

Hydram pump

\begin{abstract}
Abstrak: Tujuan dari penelitian ini adalah untuk menganalisis pengaruh kemiringan pipa outlet terhadap efisiensi pompa hidram dengan panjang pipa yang sama. Metode yang digunakan dalam penelitian ini adalah metode eksperimental dalam skala laboratorium dengan 3 perlakuan kemiringan pipa outlet yaitu $120^{\circ}, 140^{\circ}$, dan $160^{\circ}$ dengan diameter pipa outlet $1 / 2^{\prime \prime}$ dengan panjang $4 \mathrm{~m}$ dan diameter pipa inlet 1 " dengan panjang $4 \mathrm{~m}$ dan dilakukan 10 kali pengulangan. Parameter pada penelitian ini mencakup Debit, Kecepatan aliran, Bilangan Reynolds, Head Losses, dan Efisiensi pompa hidram. Berdasarkan hasil penelitian diketahui bahwa nilai debit pada sudut outlet $120^{\circ}$ memiliki nilai sebesar $6,1297 \times 10^{-5} \mathrm{~m}^{3} / \mathrm{s}$, diikuti dengan nilai debit pada sudut outlet $140^{\circ}$ dan $160^{\circ}$ berturut-turut sebesar $6,8489 \times 10^{-5} \mathrm{~m}^{3} / \mathrm{s}$. dan $7,9336 \times 10^{-5} \mathrm{~m}^{3} / \mathrm{s}$. Untuk kecepatan aliran pada sudut outlet $120^{\circ}$ didapakan nilai sebesar $0,482653 \mathrm{~m} / \mathrm{s}$ diikuti sudut outlet $140^{\circ}$ sebesar $0,539283 \mathrm{~m} / \mathrm{s}$ dan sudut outlet $160^{\circ}$ sebesar $0,624692 \mathrm{~m} / \mathrm{s}$. Dari ketiga perlakuan diketahui bahwa semakin besar sudut kemiringan outlet, maka semakin besar nilai debit dan kecepatan aliran yang dihasilkan. Bilangan reynolds pada hasil pemompaan memiliki jenis aliran laminar. Nilai Head Losses didapat pada kemiringan outlet $120^{\circ}$ sebesar $0,3565 \mathrm{~m}$. lalu diikuti kemiringan $140^{\circ}$ dan $160^{\circ}$ dengan nilai berturut-turut sebesar $0,4237 \mathrm{~m}$. dan $0,4783 \mathrm{~m}$. Nilai efisiensi pompa hidram tertinggi didapatkan pada perlakuan sudut outlet $160^{\circ}$ sebesar $99,51 \%$ (Efisiensi Rankine) dan 99,67\% (Efisiensi D'Aubuission) dengan panjang pipa yang sama. Sehingga disimpulkan nilai debit dan kecepatan aliran tertinggi diperoleh pada perlakuan sudut $160^{\circ}$. Jenis aliran bersifat Laminer dengan bilangan reynolds sebesar 950,1303. Dengan nilai efisiensi pada perlakuan kemiringan pipa outlet $160^{\circ}$ sebesar $99,51 \%$ untuk nilai efisiensi Rankine dan 99,67\% untuk efisiensi D-Aubuission. Dengan demikian Semakin besar nilai kemiringan sudut outlet yang digunakan, maka semakin besar pula nilai efisiensi pompa hidram pada panjang pipa outlet yang sama.
\end{abstract}

ABSTRACT

\section{A. LATAR BELAKANG}

Irigasi atau pengairan adalah suatu usaha untuk memberikan air guna keperluan pertanian yang dilakukan dengan tertib dan teratur. Sistem irigasi dapat diartikan suatu kesatuan yang tersusun dari berbagai komponen, menyangkut upaya penyediaan, pembagian, pengelolaan dan pengaturan air dalam rangka meningkatkan produksi pertanian, untuk itu diperlukan upaya demi kelestarian sarana irigasi dan aset-asetnyayang ada, hal ini diperlukan pengelolaan aset irigasi yang optimal (Jannata et al., 2015), (Sidharta, 2001).

Air yang digunakan sebagai usaha pengirigasian kemudian dimanfaatkan oleh tanaman dan volume air yang berlebihan akan dibuang ke saluran pembuangan. Air merupakan komponen utama yang sangat berperan penting bagi tanaman guna mendukung pertumbuhannya. Kekurangan atau kelebihan air pada tanaman akan berdampak negatif terhadap pertumbuhan dan perkembangan tanaman, bahkan berdampak langsung terhadap kualitas produksi tanaman tersebut. Usaha yang dapat dilakukan untuk memenuhi kebutuhan air tanaman sesuai dengan kebutuhannya adalah dengan cara melakukan irigasi yang teratur dengan volume air yang cukup. Salah satu alat yang digunakan dalam proses pengirigasian di bidang pertanian adalah pompa (Ansori et al., 2014).

Pompa adalah suatu alat yang digunakan untuk memindahkan suatu cairan dari suatu tempat ke tempat lain dengan cara menaikkan tekanan cairan tersebut. (Rejekiningrum \& Kartiwa, 2020). Kenaikan tekanan cairan tersebut digunakan untuk mengatasi hambatan-hambatan pengaliran. Hambatan-hambatan pengaliran itu dapat berupa perbedaan tekanan, perbedaan ketinggian atau hambatan gesek. Pompa sangat dibutuhkan di bidang pertanian pada saat musim kemarau guna menunjang keberadaan air bagi tanaman. Keberadaan pompa juga akan mengurangi ketergantungan para petani terhadap pengirigasian manual yang dilakukan dengan cara mengalirkan air secara langsung dari sungai atau parit menuju lahan pertanian (Syahputra, 2013).

Salah satu jenis pompa yang digunakan untuk proses irigasi pada bidang pertanian adalah pompa hidram. Pompa hidram merupakan alat untuk menaikkan air ke tempat yang lebih tinggi yang energi penggeraknya tidak menggunakan bahan bakar minyak ataupun tenaga listrik, melainkan 
menggunakan tekanan atau hantaman air (water hammer) yang masuk ke dalam pompa melalui pipa inlet. Masuknya air yang berasal dari pipa inlet ke dalam pompa harus berjalan secara kontinyu atau terus menerus. Pompa tanpa bahan bakar ini diharapkan dapat dimanfaatkan untuk membantu mengurangi biaya operasional untuk irigasi pertanian (Wahjono, 2006).

Ditinjau dari energi penggeraknya maka dalam pembuatan instalasi pompa hidram, posisi pompa harus lebih rendah dari sumber air atau reservoir yang dibuat. Seperti yang terdapat pada penelitian yang pernah dilakukan oleh (Herawati et al., 2009) yang menyatakan adanya pengaruh ketinggian head supply terhadap kinerja pompa hidram. Ketinggian head supply berguna untuk menjaga besarnya hantaman yang dihasilkan oleh air dan akan berdampak pada performansi pompa hidram dalam menaikkan air ke tempat yang lebih tinggi.

Selain posisi pompa, efektivitas kinerja pompa hidram dipengaruhi oleh beberapa parameter antara lain kemiringan pipa outlet pompa hidram. Kemiringan pipa outlet akan memberi dampak terhadap besarnya debit yang akan dihasilkan. Semakin besar sudut kemiringan maka semakin rendah elevasi ketinggian head ke luar pada instalasai pompa hidram. Hal ini akan berpengaruh terhadap debit pemompaan yang dihasilkan (Subroto \& Shodiqin, 2015).

Selain itu, faktor yang paling berpengaruh dalam perlakuan kemiringan sudut outlet adalah besar kecilnya energi potensial yang dihasilkan pada setiap perlakuan. Sesuai dengan persamaan energi potensial yaitu hasil kali dari massa air (m) kg, gravitasi (g) $\mathrm{m} / \mathrm{s}^{2}$, dan ketinggian titik acuan (h) $\mathrm{m}$, yang mengakibatkan adanya pengaruh energi potensial terhadap debit yang dihasilkan. Semakin tinggi elevasi ketinggian head keluar, maka energi potensial air semakin besar, dan debit yang dihasilkan semakin rendah. Energi potensial berbeanding terbalik dengan nilai debit yang dihasilkan pada setiap perlakuannya. Makin tinggi letak suatu benda terhadap titik acuan tertentu, maka makin besar pula energy potensial yang dimiliki oleh benda tersebut. Berdasarkan hal tersebut maka perlu dilakukan suatu penelitian yang berjudul "Analisis Pengaruh Kemiringan Pipa Outlet Terhadap Efisiensi Pompa Hidram ”.

Tujuan dari penelitian ini adalah untuk menganalisis pengaruh kemiringan pipa outlet terhadap efisiensi pompa hidram dengan panjang pipa yang sama.

\section{B. METODE PENELITIAN}

\section{Alat dan Alat}

Bahan yang digunakan dalam penelitian ini adalah air. Adapun alat-alat yang digunakan dalam penelitian ini antara lain: stopwatch, bak penampungan, meteran, penggaris, busur derajat, polpoint, kertas, pompa hidram.

\section{Metode}

Metode penelitian yang digunakan adalah metode eksperimental dengan 3 perlakuan kemiringan pipa outlet yaitu $120^{\circ}, 140^{\circ}$, dan $160^{\circ}$ dengan diameter outlet ${ }^{1} / 2$ " dan diameter pipa inlet 1 " dengan 10 kali pengulangan yaitu dalam skala laboratorium dengan urutan kegiatan yang sistematis dalam memperoleh data. Data hasil pengamatan disajikan dalam bentuk tabel dan grafik.

\section{Pelaksanaan penelitian}

Penelitian dilaksanakan pada bulan Maret2018 di Halaman Parkir Fakultas Teknologi Pangan dan Agroindustri Universitas. Pelaksanaan penelitian meliputi tahap persiapan dan tahap pelaksanaan. Tahap persiapan merupakan tahap penyediaan segala alat dan bahan yang akan digunakan dalam penelitian.Tahap pelaksanaan meliputi pengambilan data berupa volume air yang keluar pada pipa outlet dan volume air yang keluar pada katup limbah dan pengamatan.

\section{Parameter Peneltian}

1. Debit

Debit merupakan laju volume fluida yang dialirkan persatuan waktu. Debit yang diamati pada penelitian ini meliputi dua jenis, yaitu debit limbah atau debit buang dan debit hasil pemompaan (outlet). Untuk menentukan besar kedua jenis debit tersebut, maka digunakan persamaan (Fajar et al., 2018).

$\mathrm{Q}=\frac{\mathrm{v}}{\mathrm{t}}$

Dimana :

$\mathrm{Q}=\operatorname{Debit}\left(\mathrm{m}^{3} / \mathrm{s}\right)$

$\mathrm{V}=$ Volume $\left(\mathrm{m}^{3}\right)$

$\mathrm{t}=$ Waktu (s)

2. Kecepatan aliran

Kecepatan aliran yang diamati pada penelitian ini meliputi kecepatan aliran pada pipa inlet dan pipa outlet. Persamaan yang digunakan untuk menentukan kecepatan aliran adalah persamaan $V=\frac{\mathrm{Q}}{\mathrm{A}}$

Dimana :

$\mathrm{Q}=\operatorname{Debit}\left(\mathrm{m}^{3} / \mathrm{s}\right)$

$v=\operatorname{Kecepatan}(\mathrm{m} / \mathrm{s})$

$\mathrm{A}=$ Luas penampang $\left(\mathrm{m}^{2}\right)$

a. Bilangan Reynolds

Penentuan tipe aliran fluida ditentukan oleh bilangan Reynolds. Teori Reynolds merumuskan bahwa untukaliran internal (internal flow) atau aliran yang mengalir 
dalam pipa, jenis aliran yang terjadi dapat diketahui dengan mendapatkan bilangan Reynoldsnya dari persamaan:

$\operatorname{Re}=\frac{V x D}{w}$

Dimana :

$\mathrm{Re}=$ Bilangan Reynolds

$v=$ kecepatan aliran $(\mathrm{m} / \mathrm{s})$

$\mathrm{D}=$ diameter pipa $(\mathrm{m})$

$\mathrm{v}=$ viskositas kinematis $\left(\mathrm{m}^{2} / \mathrm{s}\right)$

b. Head losses

Nilai Head Losses yang diamati pada penelitian ini meliputi Head Losses Mayor dan Head Losses Minor. Persamaan yang digunakan untuk menentukan nilai Head Losses Mayor adalah persamaan

$\mathrm{h} f=f_{\mathrm{D}}^{\mathrm{E} 2 \mathrm{~V} g} \quad$ dan $\quad \mathrm{H} f=\frac{666,10 \times \mathrm{Q} 85,1}{\mathrm{C} 85,1 \times \mathrm{D} 85,4} \times \mathrm{L}$

(4)

Dimana:

$\mathrm{H} f \quad=$ Kerugian gesek dalam pipa (m)

$f \quad=$ Koefisien kerugian gesek yang didapat dari

dari diagram moody

$\mathrm{L} \quad=$ Panjang pipa $(\mathrm{m})$

$D \quad=$ Diameter dalam pipa $(\mathrm{m})$

$\mathrm{V}=$ Kecepatan aliran fluida $(\mathrm{m} / \mathrm{s})$

g $\quad=$ percepatan gravitasi $\left(\mathrm{m} / \mathrm{s}^{2}\right)$

$\mathrm{L} \quad=$ panjang pipa $(\mathrm{m})$

$\mathrm{D} \quad=$ diameter pipa (in)

$\mathrm{Q}=$ debit aliran $\left(\mathrm{m}^{3} / \mathrm{h}\right)$

$\mathrm{C} \quad=$ koefisien Hazen-Williams

sedangkan persamaan yang digunakan untuk menentukan nilai Head Losses Minor adalah persamaan

$\mathrm{h}_{\mathrm{m}}=\Sigma \mathrm{k} \frac{\mathrm{v}^{2}}{2 \mathrm{~g}} \mathrm{dan} \quad \mathrm{hc}=\left[\left(\frac{1}{\mathrm{c}}-1\right)\right]^{2} \frac{\mathrm{v}^{2}}{2 \mathrm{~g}}$

(5)

Dimana:

$\mathrm{h}_{\mathrm{m}} \quad=$ Head losses minor $(\mathrm{m})$

$\Sigma \mathrm{k} \quad=$ jumlah koefisien rugi minor

$\mathrm{v} \quad=$ Kecepatan aliran fluida $(\mathrm{m} / \mathrm{s})$

$\mathrm{g} \quad=$ percepatan gravitasi $\left(\mathrm{m} / \mathrm{s}^{2}\right)$

$h_{\mathrm{c}}=$ Kerugian head pada bagian perubahan

$$
\begin{array}{ll} 
& \text { penampang }(\mathrm{m}) \\
v^{2} & =\text { kecepatan rata-rata }(\mathrm{m} / \mathrm{s}) \\
g & =\text { percepatan gravitasi } 9,81\left(\mathrm{~m} / \mathrm{s}^{2}\right) \\
C & =\text { Faktor kontraksi } \\
\text { c. } & \text { Efisiensi pompa hidram }
\end{array}
$$

Besaran nilai untuk menentukan efisiensi atau performansi pompa hidram dalam memompa sejumlah volume air pada penelitian ini dapat ditentukan dengan persamaan
$\eta_{A}=\frac{q(H+h)}{(Q+q) H} \times 100 \%$ dan $\eta \mathrm{R}=\frac{q h}{Q H} \times 100 \%$

Dimana :

ఇA =efisiensi pompa hidram menurut D'Aubuission

$\eta \mathrm{R}=$ efisiensi pompa hidram menurut Rankine (\%)

$\mathrm{q}=$ debit air hasil pemompaan $\left(\mathrm{m}^{3} / \mathrm{s}\right)$

$\mathrm{Q}=$ debit air yang terbuang melalui katup limbah

$\left(\mathrm{m}^{3} / \mathrm{s}\right)$

$\mathrm{h} \quad=$ Head ke luar $(\mathrm{m})$

$\mathrm{H}=$ Head masuk (m)

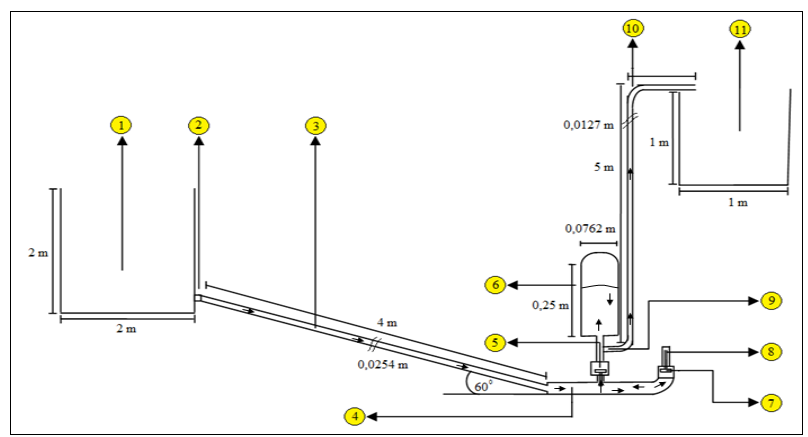

Gambar 1. Desain Penelitian

\section{Keterangan :}

1. Bak penggerak

2. Katup inlet

3. Pipa penggerak (inlet)

4. Badan pompa

5. Katup pengantar

6. Tabung udara

7. Katup limbah

8. Water hammer

9. Katup outlet

10. Pipa tekan (outlet)

11. Bak penampung (reservoir)

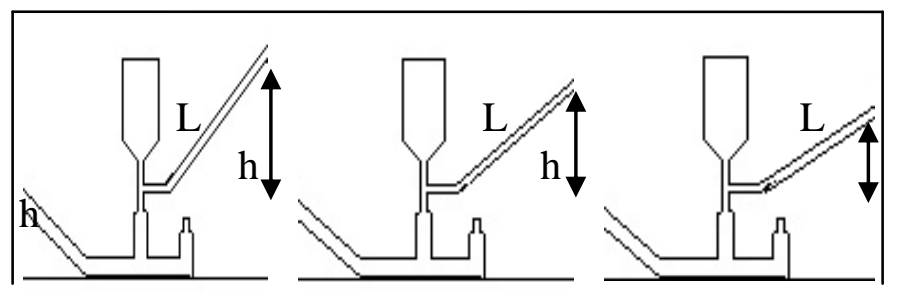

Gambar 2. Desain Perlakuan Penelitian Dengan Sudut Kemiringan Pipa Outlet $120^{\circ}, 140^{\circ}$ dan $160^{\circ}$ Keterangan :

$\mathrm{L}=$ panjang pipa outlet $(4 \mathrm{~m})$

$\mathrm{h}=$ ketinggian head keluar $(\mathrm{m})$ 


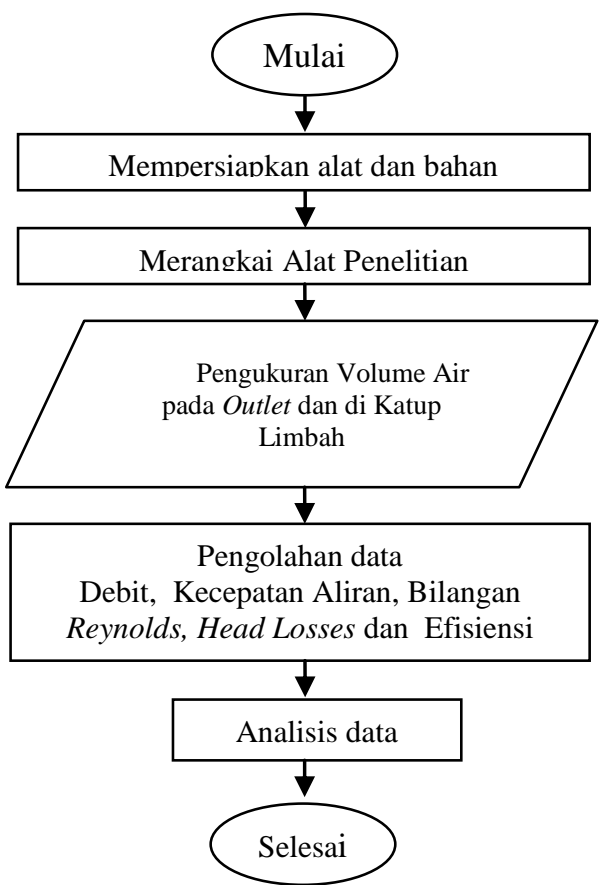

Gambar 3. Diagram Alir

\section{HASIL DAN PEMBAHASAN}

Penelitian ini berjudul Analisis Pengaruh Kemiringan Pipa Outlet Terhadap Efisiensi Pompa Hidram. Penelitian dilakukan untuk menganalisis debit aliran, kecepatan aliran, head losses dan efisiensi pompa hidram dengan tiga perlakuan pada kemiringan sudut outlet yaitu sudut $120^{\circ}, 140^{\circ}$, dan $160^{\circ}$. Penelitian ini menggunakan metode eksperimental dengan dilakukan proses trial terlebih dahulu. Proses trial dilakukan pada instalasi pompa hidram dari semua bagian pompa hidram. Proses trial ini dilakukan untuk mendapatkan konfigurasi optimal untuk parameterparameter yang ditetapkan pada pompa hidram tersebut. Selain itu proses trial juga dilakukan untuk mengetahui kekurangan-kekurangan yang terdapat pada instalasi pompa hidram, sehinggga pada saat pengambilan data, pompa hidram akan berada dalam konfigurasi optimal.

Rangkaian instalasi yang digunakan pada penelitian ini dengan ketinggian bak penggerak/ head masuk $(\mathrm{H}) 1,5 \mathrm{~m}$, panjang pipa inlet $4 \mathrm{~m}$ dengan diameter 1 inch, panjang pipa outlet $4 \mathrm{~m}$ dengan diameter $1 / 2$ inch. Spesifikasi pompa hidram yang digunakan adalah sebagai berikut :

Tinggi Tabung Udara $: 34 \mathrm{~cm}$

Diameter Tabung Udara: 3 inch

Panjang Badan Pompa : $32 \mathrm{~cm}$

Diameter Inlet $\quad: 1$ inch

Diameter Outlet: $1 / 2$ inch

T Badan Pompa $\quad: 1^{1 / 2}$ inch

T Outlet $\quad: 1$ inch

Berat Palu Air $\quad: 300$ gr

\section{Debit Aliran}

Debit air adalah banyaknya volume zat cair yang mengalir pada tiap satu satuan waktu, biasanya dinyatakan dalam satuan liter/detik atau dalam satuan meter kubik/detik $\left(\mathrm{m}^{3} / \mathrm{s}\right)$ (Hidayat et al., 2013). Pengukuran debit pada penelitian ini dilakukan untuk mengetahui perbedaan jumlah debit yang dihasilkan pada setiap perlakuan yang berbeda. Pengukuran debit pada penelitian ini dilakukan pada dua bagian yaitu di pipa outlet dan di palu air (Water Hammer) atau yang biasa disebut dengan air limbah. Pengukuruan debit pada kedua bagian ini dilakukan dengan cara menampung jumlah air yang keluar melalui pipa outlet dan palu air (water hammer) menggunakan ember sehingga diketahui volume air yang keluar dari kedua bagian tersebut. Pengambilan data debit dilakukan dengan sepuluh kali ulangan pada setiap perlakuan yang kemudian dimbil nilai rata-rata dari ulangan tersebut. Dari hasil penelitian diperoleh data debit aliran dari berbagai perlakuan yang berbeda sebagaimana tertera pada Tabel 1 berikut.

Tabel 1.

Hasil Perhitungan Debit Outlet (q)

\begin{tabular}{cc}
\hline Perlakuan & $\begin{array}{c}\text { Debit (q) } \\
\left(\mathrm{m}^{3} / \mathrm{s}\right)\end{array}$ \\
\hline Sudut Kemiringan Outlet $120^{\circ}$ & $6,1297 \times 10^{-5}$ \\
Sudut Kemiringan Outlet $140^{\circ}$ & $6,8489 \times 10^{-5}$ \\
Sudut Kemiringan Outlet $160^{\circ}$ & $7,9336 \times 10^{-5}$ \\
\hline
\end{tabular}

Berdasarkan data dari tabel menunjukkan bahwa pada sudut outlet $120^{\circ}$ memiliki nilai debit sebesar $6,1297 \times 10^{-5} \mathrm{~m} 3 / \mathrm{s}$, diikuti dengan nilai debit pada sudut outlet $140^{\circ}$ sebesar $6,8489 \times 10^{-5} \mathrm{~m}^{3} / \mathrm{s}$. Kemudian pada sudut outlet $160^{\circ}$ didapatkan nilai debit sebesar $7,9336 \times 10^{-5}$ $\mathrm{m}^{3} / \mathrm{s}$. Dari ketiga perlakuan diketahui bahwa semakin besar nilai sudut kemiringan outlet, maka semakin besar pula jumlah debit yang dihasilkan. Sebagaimana dari grafik bahwa nilai debit terbesar didapatkan pada perlakuan dengan sudut outlet $160^{\circ}$. Sedangkan nilai debit terkecil didapatkan pada perlakuan sudut outlet $120^{\circ}$. Kenaikan nilai debit yang signifikan dari ketiga perlakuan tersebut karena adanya pengaruh besar sudut outlet terhadap ketinggian head ke luar pada instalasi pompa hidram. Semakin besar sudut kemiringan maka semakin rendah elevasi ketinggian head ke luar pada instalasai pompa hidram. Hal ini akan berpengaruh terhadap debit pemompaan yang dihasilkan. Pernyataan di atas sesuai dengan teori yang menyatakan bahwa semakin rendah elevasi ketinggian head ke luar (bak penampung) 
maka semakin besar pula debit yang dihasilkan pada proses pemompaan. Adapun pernyataan yang lain yang menyatakan bahwa semakin rendah ketinggian elevasi head ke luar (bak penampung) maka katup limbah akan bekerja secara optimal sehingga kapasitas aliran yang masuk pada pipa pemasukan semakin besar (Hazwi,2014).

Selain itu, faktor yang paling berpengaruh dalam perlakuan kemiringan sudut outlet adalah besar kecilnya energi potensial yang dihasilkan pada setiap perlakuan. Sesuai dengan persamaan energi potensial yaitu hasil kali dari massa air (m) $\mathrm{kg}$, gravitasi (g) $\mathrm{m} / \mathrm{s}^{2}$, dan ketinggian titik acuan (h) $m$, yang mengakibatkan adanya pengaruh energi potensial terhadap debit yang dihasilkan. Semakin tinggi elevasi ketinggian head keluar, maka energi potensial air semakin besar, dan debit yang dihasilkan semakin rendah. Energi potensial berbeanding terbalik dengan nilai debit yang dihasilkan pada setiap perlakuannya. Makin tinggi letak suatu benda terhadap titik acuan tertentu, maka makin besar pula energy potensial yang dimiliki oleh benda tersebut. Untuk lebih jelasnya bisa dilihat seperti Gambar 4.

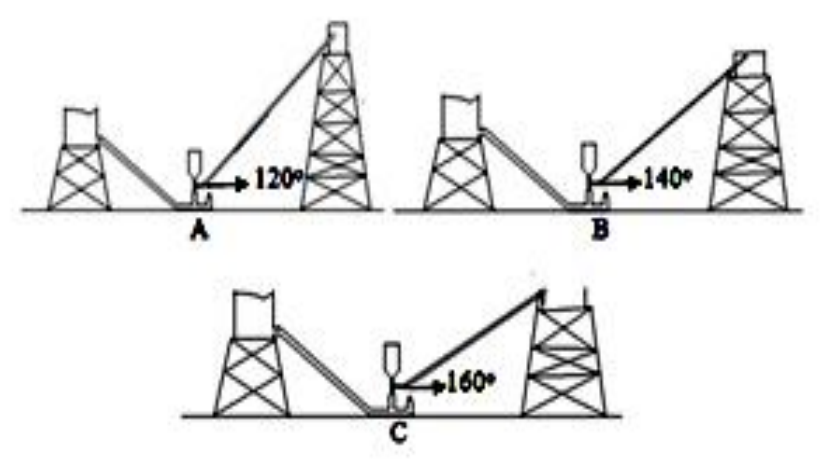

Gambar 4. A kemiringan sudut outlet $120^{\circ}$, B Kemiringan sudut outlet $140^{\circ}$, C Kemiringan sudut outlet $160^{\circ}$

Berdasarkan Gambar 4 di atas dapat dijelaskan bahwa terdapat pengaruh besar sudut outlet terhadap elevasi ketinggian bak penampung. Perhitungan besar kemiringan sudut outlet dilakukan menggunakan busur derajat. Perhitungan sudut diambil dari sudut bagian dalam/sudut yang menghadap ke atas.

Debit air limbah penting diketahui untuk mendapatkan nilai efisiensi dari pompa hidram. Dari penelitian yang sudah dilakukan didapatkan nilai debit air limbah seperti pada Tabel 2 berikut.
Tabel 2.

Hasil Perhitungan Debit Limbah (Q)

\begin{tabular}{llll}
\hline Perlakuan & $\begin{array}{l}\text { Volume } \\
\text { Rata-Rata } \\
\left(\mathrm{m}^{3}\right)\end{array}$ & $\begin{array}{l}\text { Wak } \\
\text { tu } \\
(\mathrm{s})\end{array}$ & $\begin{array}{l}\text { Debit (Q) } \\
(\mathrm{m} 3 / \mathrm{s})\end{array}$ \\
\hline Sudut Outlet $120^{\circ}$ & $8,9734 \times 10^{-3}$ & 60 & $1,49555 \times 10^{-4}$ \\
${\text { Sudut Outlet } 140^{\circ}}^{\circ}$ & $9,4155 \times 10^{-3}$ & 60 & $1,54595 \times 10^{-4}$ \\
${\text { Sudut Outlet } 160^{\circ}}^{9,5678 \times 10^{-3}}$ & 60 & $1,59459 \times 10^{-4}$ \\
\hline
\end{tabular}

Berdasarkan data pada Tabel 2 di atas didapatkan nilai debit yang berbeda pada setiap perlakuan. Pada sudut outlet $120^{\circ}$ didapatkan nilai debit sebesar $0,00014955 \mathrm{~m}^{3} / \mathrm{s}$. Diikuti dengan nilai debit pada sudut outlet $140^{\circ}$ yaitu sebesar $0,00015459 \mathrm{~m}^{3} / \mathrm{s}$ dan pada sudut outlet $160^{\circ}$ didapatkan nilai debit sebesar o,00015945 $\mathrm{m}^{3} / \mathrm{s}$. Dari data tersebut diketahui bahwa nilai debit terbesar didapatkan pada sudut outlet $160^{\circ}$ dan yang terkecil adalah pada sudut outlet $120^{\circ}$. Dengan adanya pengaruh besar kemiringan sudut outlet terhadap elevasi ketinggian head ke luar, maka hal tersebut akan berpengaruh pula terhadap hantaman palu air pada katup limbah. Semakin rendah elevasi ketinggian head ke luar maka air yang mengalir melalui pipa inlet semakin keras dan aliran semakin cepat, sehingga banyak air yang akan ke luar dari katup limbah.

\section{Kecepatan Aliran}

Kecepatan aliran didapatkan dari hasil pembagian debit (q) dengan luas penampang aliran (Wismarini \& Ningsih, 2011) .

Berdasarkan hasil perhitungan menggunakan persamaan di atas didapatkan nilai kecepatan aliran pada setiap perlakuan seperti pada Tabel 3 di bawah ini.

Tabel 3.

Hasil Perhitungan Kecepatan Aliran Outlet(v)

\begin{tabular}{rc}
\hline Perlakuan & Kecepatan Aliran (m/s) \\
\hline Sudut Outlet $120^{\circ}$ & 0,482653 \\
Sudut Outlet $140^{\circ}$ & 0,539283 \\
Sudut Outlet $160^{\circ}$ & 0,624692 \\
\hline
\end{tabular}

Berdasarkan Tabel 3 didapatkan bahwa nilai kecepatan aliran yang berbeda-berbeda pada setiap perlakuan. Pada sudut outlet $120^{\circ}$ didapakan nilai kecepatan aliran sebesar $0,482653 \mathrm{~m} / \mathrm{s}$ diikuti dengan nilai kecepatan aliran pada sudut outlet $140^{\circ}$ yaitu sebesar $0,539283 \mathrm{~m} / \mathrm{s}$ dan nilai kecepatan aliran pada sudut outlet $160^{\circ}$ didapatkan sebesar o,624692 $\mathrm{m} / \mathrm{s}$. Dari uraian data di atas diketahui bahwa pada sudut outlet $160^{\circ}$ memiliki kecepatan 
aliran yang paling besar dan sudut outlet $120^{\circ}$ memiliki kecepatan aliran yang paling rendah. Adanya perbedaan nilai kecepatan aliran pada awalnya disebabkan oleh besar kemiringan sudut outlet yang digunakan pada setiap perlakuan. Kemiringan sudut outlet akan berpengaruh langsung terhadap elevasi ketinggian head ke luar. Hal tersebut juga akan berpengaruh terhadap debit pemompaan yang dihasilkan. Semakin rendah elevasi ketinggian head keluar (bak penampung) maka semakin besar pula debit yang dihasilkan pada proses pemompaan. Nilai debit tersebut akan mempengaruhi besar kecilnya nilai kecepatan aliran. Nilai kecepatan

aliran didapatkan dari perbandingan antara nilai debit dengan luas penampang. Pada penelitian ini, nilai debit yang dihasilkan berbeda-beda pada setiap perlakuannya. Sedangkan luas penampang yang digunakan adalah tetap/konstan sehingga menyebabkan nilai kecepatan aliran akan mengalami kenaikan pada setiap perlakuannya. Semakin besar debit yang dihasilkan maka semakin besar pula nilai kecepatan aliran yang dihasilkan. Sebagaimana yang terjadi pada setiap perlakuan, bahwa terdapat nilai debit yang berbeda, sehingga menghasilkan nilai kecepatan aliran yang berbeda-beda.

\section{Bilangan Reynolds}

Ada tiga faktor yang mempengaruhi perbedaan aliran yaitu kekentalan atau viskositas zat cair $(\mu)$, massa zat cair $(\rho)$, dan diameter pipa (D). Viskositas adalah ukuran yang menyatakan kekentalan suatu cairan atau fluida. Kekentalan merupakan sifat cairan yang berhubungan erat dengan hambatan untuk mengalir. Beberapa cairan ada yang dapat mengalir cepat, sedangkan lainnya mengalir secara lambat. Cairan yang mengalir cepat seperti contohnya air, alkohol, dan bensin karena memiliki nilai viskositas kecil. Sedangkan cairan yang mengalir lambat seperti gliserin, minyak asto, dan madu karena mempunyai viskositas besar. Jadi viskositas tidak lain menentukan kecepatan mengalirnya suatu cairan.
Tabel 4.

Hasil Perhitungan Bilangan Reynolds

\begin{tabular}{rcc}
\hline Perlakuan & $\begin{array}{c}\text { Bilangan } \\
\text { Reynolds }\end{array}$ & $\begin{array}{c}\text { Jenis } \\
\text { Aliran }\end{array}$ \\
\hline Sudut Outlet $120^{\circ}$ & 734,0949 & Laminar \\
Sudut Outlet $140^{\circ}$ & 820,2268 & Laminar \\
Sudut Outlet $160^{\circ}$ & 950,1303 & Laminar \\
\hline
\end{tabular}

Berdasarkan hasil perhitungan bilangan reynolds yang terdapat pada Tabel 4 diketahui bahwa dari semua perlakuan didapatkan jenis aliran laminar dengan nilai bilangan Reynolds di bawah 2300. Hal ini sesuai bahwa aliran laminar adalah aliran fluida yang bergerak dalam lapisan-lapisan dengan satu lapisan meluncur dengan lancar. Aliran laminar memiliki kisaran nilai bilangan Reynolds kurang dari 2300 (Dharma \& Prasetyo, 2012).

Bilangan reynolds pada sudut pipa outlet $160^{\circ}$ memiliki nilai yang lebih tinggi dari perlakuan pipa outlet dengan sudut $120^{\circ}$ dan $140^{\circ}$, hal ini disebabkan oleh nilai kecepatan aliran yang terjadi pada sudut $160^{\circ}$ yang lebih tinggi dari sudut yang lainnya.

\section{Head Losses Total}

Head losses total merupakan jumlah kehilangan energi selama pengaliran berlangsung, yaitu kehilangan energi primer akibaPercepatan pengembangan pertanian lahan kering iklim kering di Nusa Tenggarat gesekan antara zat cair dengan dinding pipa, dan kehilangan energi sekunder akibat perubahan penampang pipa, sambungan, belokan, serta katub. Sesuai dengan prinsip Bernoulli, tinggi energi total di setiap titik pada saluran pipa adalah jumlah dari tinggi elevasi, tinggi tekanan, dan tinggi kecepatan (Puspawan, 2013).

Nilai Head losses total atau kehilangan energi total diperoleh dengan menambahkan nilai kehilangan energi primer dengan nilai kehilangan energi sekunder baik kehilangan energi akibat belokan, pembesaran penampang mendadak, pengecilan mendadak, dan katub. Dari hasil penelitian yang sudah dilakukan didapatkan nilai Head Losses seperti yang tertera pada Gambar 5 di bawah. 


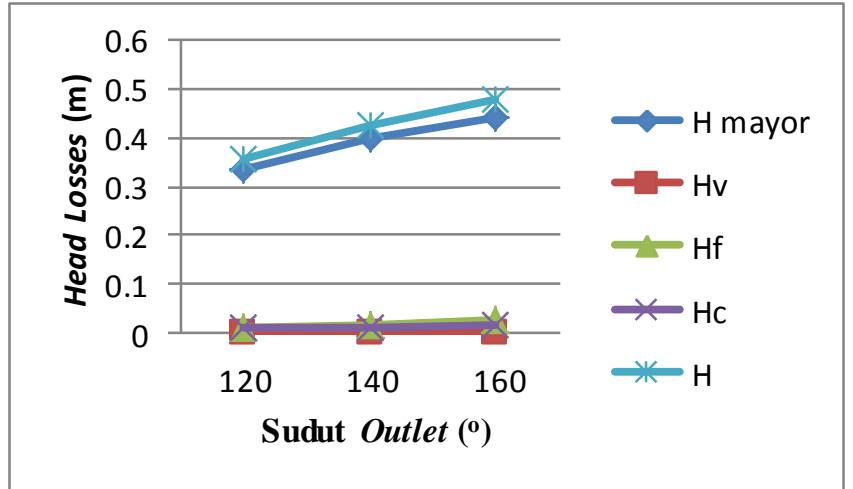

Gambar 5. Grafik Hasil Perhitungan Head Losses

Keterangan

$\mathrm{H}_{v} \quad=$ Kerugian head pada katup (m)

$\mathrm{H}_{f} \quad=$ Kerugian head pada belokan (m)

$\mathrm{H}_{\mathrm{c}}=$ Kerugian karena perubahan penampang (m)

$\mathrm{H}=$ Head Total $(\mathrm{m})$

Berdasarkan grafik pada Gambar 5 di atas diketahui bahwa Head Losses pada masingmasing perlakuan memiliki nilai yang berbedaberbeda. Nilai Head Losses pada perlakuan kemiringan outlet $120^{\circ}$ adalah sebesar $0,3565 \mathrm{~m}$. Nilai head losses tersebut merupakan nilai yang paling rendah di antara tiga perlakuan tersebut. Nilai Head Losses pada perlakuan sudut kemiringan $140^{\circ}$ adalah sebesar $0,4237 \mathrm{~m}$. Sedangkan nilai Head Lossess pada perlakuan $160^{\circ}$ adalah sebesar $0,4783 \mathrm{~m}$. Pada perlakuan sudut kemiringan $160^{\circ}$ memiliki nilai Head Losses paling besar karena mempunyai debit dan kecepatan aliran yang paling besar. Dengan kata lain head losses aliran berbanding lurus dengan kecepatan aliran. Jika kecepatan aliran meningkat maka head losses aliran akan meningkat pula demikian juga berlaku sebaliknya.

\section{Efisiensi Pompa Hidram}

Efisiensi pompa hidram dapat dihitung dengan menggunakan dua metode yaitu efisiensi $D$-Aubuission dan efisiensi Rankine (Siswadi, 2016; Wibowo, 2019). Pada penelitian ini kedua metode tersebut digunakan untuk menghitung efisiensi pompa hidram. Hasil dari perhitungan efisiensi pompa hidram pada penelitian ini bisa dilihat pada grafik pada Gambar 6 berikut.

\section{0

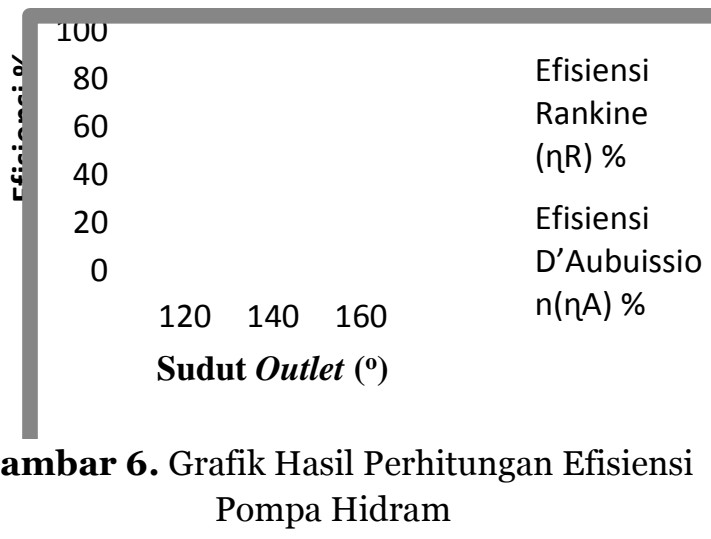

Penggunaan variasi sudut kemiringan pipa outlet pada penelitian menunjukkan hasil yang signifikan antara efisiensi dengan ketiga perlakuan yang sudah ditetapkan. Berdasarkan grafik pada Gambar 6 di atas, menunjukkan bahwa nilai efisiensi yang mendekati $100 \%$ adalah pada perlakuan dengan kemiringan pipa outlet $160^{\circ}$ yaitu sebesar $99,51 \%$ untuk nilai efisiensi Rankine dan 99,67\% untuk efisiensi $D$ Aubuission. Nilai efisiensi berbading lurus dengan nilai sudut kemiringan outlet dengan panjang pipa yang sama pada pompa hidram. Semakin besar nilai kemiringan sudut outlet yang digunakan, maka semakin besar pula nilai efisiensi pada pompa hidram tersebut dengan panjang pipa outlet yang sama. Hal ini terjadi karena adanya pengaruh kemiringan pipa outlet terhadap ketinggian instalasi head ke luar pada pompa hidram (Dinamis et al., 2013). Nilai efisiensi yang didapatkan pada penelitian ini hanya ditinjau dari kemiringan sudut outlet pompa hidram.

\section{SIMPULAN}

Variasi sudut kemiringan pipa outlet pada pompa hidram yaitu $120^{\circ}, 140^{\circ}$, dan $160^{\circ}$. Ketiga jenis perlakuan tersebut menunjukkan hasil yang berbeda dari semua parameter yang telah ditetapkan. Nilai debit tertinggi yang diperoleh dari penelitian ini adalah pada perlakuan sudut $160^{\circ}$ dan yang paling rendah adalah pada perlakuan sudut $120^{\circ}$. Jenis aliran yang terjadi pada ketiga perlakuan penelitian ini adalah aliran Laminer dengan bilangan reynolds di bawah 2300 yaitu sebesar 734,0949 untuk sudut $120^{\circ}, 820,2268$ untuk sudut $140^{\circ}$, dan 950,1303 untuk sudut $160^{\circ}$. Nilai efisiensi yang mendekati $100 \%$ adalah pada perlakuan dengan kemiringan pipa outlet $160^{\circ}$ yaitu sebesar 99,51\% untuk nilai efisiensi Rankine dan 99,67\% untuk efisiensi D-Aubuission. Nilai efisiensi berbading lurus dengan nilai sudut 
kemiringan outlet pada pompa hidram. Semakin besar nilai kemiringan sudut outlet yang digunakan, maka semakin besar pula nilai efisiensi pada pompa hidram pada panjang pipa outlet yang sama.

\section{DAFTAR RUJUKAN}

Ansori, A., Ariyanto, A., \& Syahroni, S. (2014). Kajian efektifitas dan efisiensi jaringan irigasi terhadap kebutuhan air pada tanaman padi (Studi kasus irigasi Kaiti Samo Kecamatan Rambah Kabupaten Rokan Hulu). Jurnal Mahasiswa Teknik Universitas Pasir Pengaraian.

Dharma, U. S., \& Prasetyo, G. (2012). PENGARUH PERUBAHAN LAJU ALIRAN TERHADAP TEKANAN DAN JENIS ALIRAN YANG TERJADI PADA ALAT UJI PRAKTIIKUM MEKANIKA FLUIDA. Turbo : Jurnal Program Studi Teknik Mesin. https://doi.org/10.24127/trb.v1i2.653

Dinamis, J., Departemen, M., Mesin, T., Teknik, F., Utara, U. S., Pengajar, S., Teknik, D., Teknik, F., \& Sumatera, U. (2013). Rancang Bangun Dan Uji Eksperimental Pengaruh Variasi Panjang Driven Pipe Dan Diameter Air Chamber Terhadap Efisiensi Pompa Hidram. Jurnal Dinamis.

Fajar, A., Abdullah, S. H., \& Priyati, A. (2018). Rancang bangun dan uji kinerja sistem kontrol fertigasi dengan irigasi tetes. 5(1), 19-29.

Herawati, Y., Teknik, F., \& Muhammadiyah, U. (2009). Panjang Pipa Inlet terhadap Efisiensi Pompa Hidram. Dinamika Teknik Sipil.

Hidayat, Y., Murtilaksono, K., Wahjunie, E. D., \& Panuju, D. R. (2013). Pencirian Debit Aliran Sungai Citarum Hulu ( The Characteristics of River Discharge of Citarum Hulu ). Jurnal Ilmu Pertanian Indonesia.

Jannata, J., Abdullah, S., \& Priyati, A. (2015). Analisa Kinerja Pengelolaan Irigasi Di Daerah Irigasi Lemor, Kabupaten Lombok Timur, Nusa Tenggara Barat. Jurnal Ilmiah Rekayasa Pertanian Dan Biosistem.

Puspawan, A. (2013). Analisa Rugi-Rugi Instalasi Pipa dan Pompa Reciprocating di PT. Pertamina EP-Region Area Prabumulih Provinsi Sumatera Selatan. Teknosia.

Rejekiningrum, P., \& Kartiwa, B. (2020). Pengembangan Sistem Irigasi Pompa Tenaga Surya Hemat Air Dan Energi Untuk Antisipasi Perubahan Iklim Di Kabupaten Bantul, Daerah Istimewa Yogyakarta. Jurnal Tanah Dan Iklim. https://doi.org/10.21082/jti.v41n2.2017.159-171

Sidharta, S. . (2001). Irigasi dan Bangunan Air. Journal of Chemical Information and Modeling .

Siswadi. (2016). ANALISIS TEKANAN POMPA TERHADAP DEBIT AIR Siswadi 5. JURNAL ILMUILMU TEKNIK - SISTEM.

Subroto, S., \& Shodiqin, S. (2015). PENGARUH VOLUME TABUNG TEKAN TERHADAP UNJUK KERJA POMPA HIDRAM. Media Mesin: Majalah Teknik Mesin. https://doi.org/10.23917/mesin.v16i2.1512

Syahputra, B. (2013). Model pompa air dengan tenaga angin untuk pemanfaatan irigasi sawah. Prosiding Seminar Nasional Sains Dan Teknologi Fakultas Teknik.
Wahjono, H. D. (2006). Pompa Hidram. Jurnal Akutansi Indonesia.

Wibowo, B. S. (2019). PENGARUH VARIASI DIAMETER PIPA INPUT DAN PIPA OUTPUT TERHADAP KINERJA POMPA HIDRAM. Machine: Jurnal Teknik Mesin. https://doi.org/10.33019/jm.v5i2.1366

Wismarini, T., \& Ningsih, D. (2011). Metode Perkiraan Laju Aliran Puncak (Debit Air) sebagai Dasar Analisis Sistem Drainase di Daerah Aliran Sungai Wilayah Semarang Berbantuan SIG. None. 